Images in...

\title{
Cranial neuropathy because of IgG4-related pachymeningitis; intracranial and spinal mass lesions
}

\author{
Yasutaka Tajima, Yasunori Mito \\ Department of Neurology, Sapporo City General Hospital, Brain Health Center, Sapporo, Japan
}

Correspondence to Dr Yasutaka Tajima, yasutaka.tajima@doc.city.sapporo.jp

\section{DESCRIPTION}

A 64-year-old man suffering from chronic heart failure developed gradually worsening dysphagia 1 month before. Physical examinations revealed no abnormalities, such as proptosis and parotid swelling. Neurological examinations revealed hoarseness, poor soft palate elevation and rightsided atrophy of the tongue and sternocleidomastoid muscle. The patient's DTRs were slightly hypoactive, but no pathological reflexes were elicited. Cerebellar systems were intact, and there was no muscle weakness in the four extremities. Gadolinium-enhanced MRI disclosed mass lesions in the right skull base and thoracic spine, though clinical symptoms suggestive of myelopathy were absent (figure 1: arrows). Cerebrospinal fluid (CSF) contained 14 cells (mono: 3, poly 11)/ $\mathrm{mm}^{3}$, and $260 \mathrm{mg} / \mathrm{dl}$ of protein. Laboratory examinations demonstrated that serum IgG4 was elevated to $221 \mathrm{mg} / \mathrm{dl}$ (normal < $104 \mathrm{mg} / \mathrm{dl}$ ). Systemic CT examinations showed slight swelling of both kidneys that was compatible with an IgG4-related renal disorder, but no other organ involvements were detected. Open biopsy of the thoracic lesion was performed, and pathological investigations revealed non-specific granulation with inflammatory infiltrates (figure 2A). Immunohistochemical examinations showed IgG4-positive plasma cells (figure 2B). Subsequently, steroid pulse therapy and tapering of oral prednisolone were administered. Three weeks after completing steroid treatment, the patient's manifestations and radiological
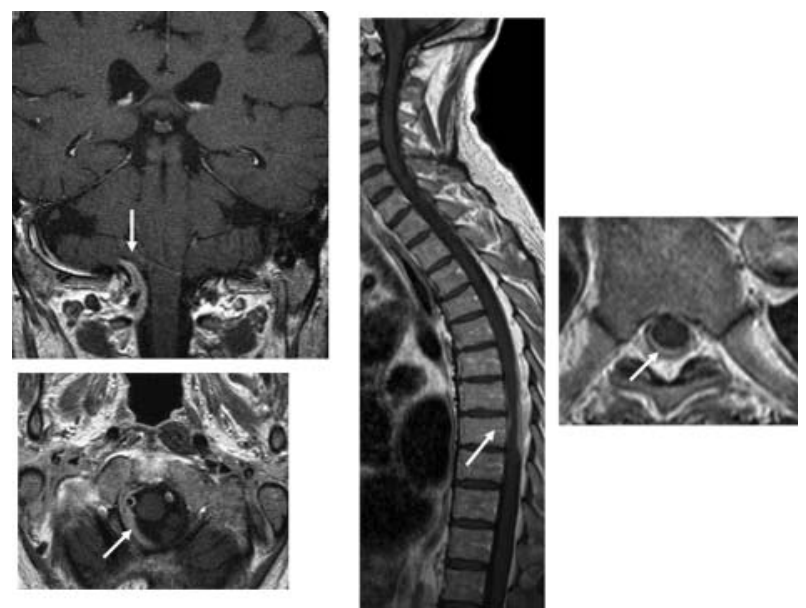

Figure 1 MRls on admission.
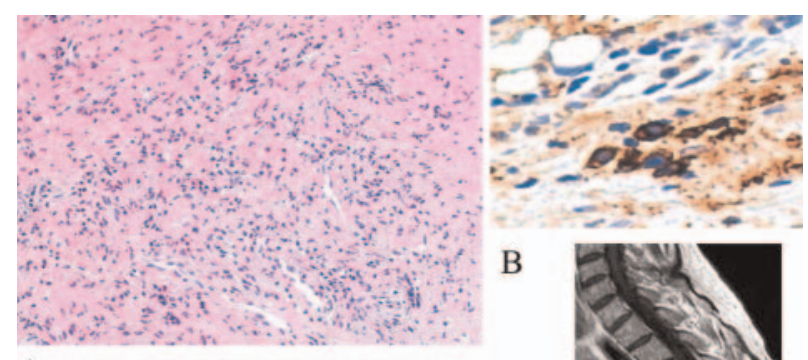

A

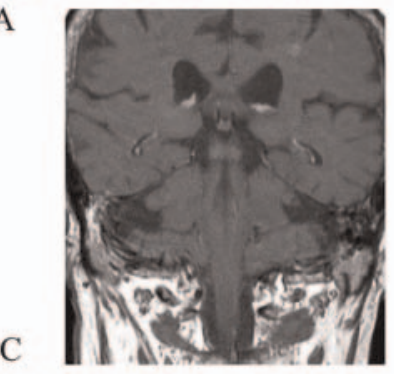

B

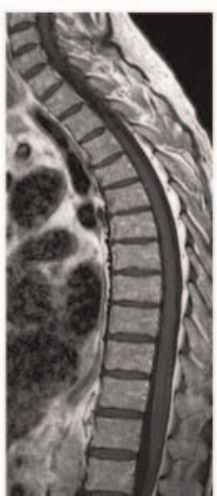

Figure 2 Pathological findings $(A, B)$ and MRls after steroid treatment $(C, D)$.

findings were markedly improved (figure 2 C,D). Recently, IgG4-related diseases characterised by infiltration of IgG4-positive plasma cells and sclerosing changes in organs have emerged as a distinct new disease entity. ${ }^{1}$ Among the features of this entity, central nervous system involvements due to pachymeningitis has received considerable clinical attention in making the differential diagnosis and determining pathogenesis. ${ }^{2} 3$

\section{Learning points}

- IgG4-related pachymeningitis could involve spinal cord.

- Pathological examination is necessary.

- Treatment with prednisolone should be effective.

Competing interests None.

Patient consent Obtained.

\section{REFERENCES}

1. Stone JH, Zen Y, Deshpande V. Mechanisms of disease. IgG4-Related Disease. N Engl J Med 2012;366;539-51. 


\section{BMJ Case Reports}

2. Chan SK, Cheuk W, Chan KT, et al. IgG4-related sclerosing pachymeningitis: a previously unrecognized dorm of central nervous system involvement in IgG4-related sclerosing disease. Am J Surg Pathol 2009;33:1249-52.
3. Lindstrom KM, Cousar JB, Lopes MB. IgG4-related meningeal disease: clinico-pathological features and proposal for diagnostic criteria. Acta Neuropathol 2010;120:765-76.

This pdf has been created automatically from the final edited text and images.

Copyright 2012 BMJ Publishing Group. All rights reserved. For permission to reuse any of this content visit http://group.bmj.com/group/rights-licensing/permissions.

BMJ Case Report Fellows may re-use this article for personal use and teaching without any further permission.

Please cite this article as follows (you will need to access the article online to obtain the date of publication).

Tajima Y, Mito Y. Cranial neuropathy because of IgG4-related pachymeningitis; intracranial and spinal mass lesions. BMJ Case Reports 2012;10.1136/bcr-2012006471, Published XXX

Become a Fellow of BMJ Case Reports today and you can:

- Submit as many cases as you like

- Enjoy fast sympathetic peer review and rapid publication of accepted articles

- Access all the published articles

- Re-use any of the published material for personal use and teaching without further permission

For information on Institutional Fellowships contact consortiasales@bmjgroup.com

Visit casereports.bmj.com for more articles like this and to become a Fellow 